\title{
When the Scars Begin to Heal: Narratives of Obstetric Violence in Chiapas, Mexico
}

DOI:

10.1108/IJHG-05-2017-0022

\section{Document Version}

Accepted author manuscript

Link to publication record in Manchester Research Explorer

\section{Citation for published version (APA):}

Murray De Lopez, J. (2018). When the Scars Begin to Heal: Narratives of Obstetric Violence in Chiapas, Mexico. International Journal of Health Governance, 23(1), 60-69. https://doi.org/10.1108/lJHG-05-2017-0022

\section{Published in:}

International Journal of Health Governance

\section{Citing this paper}

Please note that where the full-text provided on Manchester Research Explorer is the Author Accepted Manuscript or Proof version this may differ from the final Published version. If citing, it is advised that you check and use the publisher's definitive version.

\section{General rights}

Copyright and moral rights for the publications made accessible in the Research Explorer are retained by the authors and/or other copyright owners and it is a condition of accessing publications that users recognise and abide by the legal requirements associated with these rights.

\section{Takedown policy}

If you believe that this document breaches copyright please refer to the University of Manchester's Takedown Procedures [http://man.ac.uk/04Y6Bo] or contact uml.scholarlycommunications@manchester.ac.uk providing relevant details, so we can investigate your claim.

\section{OPEN ACCESS}


International Journal of Health Governance (ISSN: 2059-4631)

Final version accepted for publication (15th June 2017)

When the Scars Begin to Heal:

Narratives of Obstetric Violence in Chiapas, Mexico

\begin{abstract}
Purpose - The purpose is to examine how obstetric violence is embodied and understood by the women who experience it, how it impacts on maternal subjectivity and what the long-term health implications may be.
\end{abstract}

Design/methodology/approach - This paper is a qualitative, non-clinical analysis of women's experiences of obstetric violence in Mexico. Data sources are derived from ethnographic interviews, participant observation and an extensive revision of public reports and policy.

Findings - Local ideas and beliefs over what one must endure to become a 'good mother', contributes to how acts of obstetric violence are treated and interpreted by professionals, the community and the individual alike. The ways in which women interpret violence in relation to the wider context of their everyday lives, has significant implications for evaluating the effectiveness of approaches to reproductive and maternal health.

Social implications - Situating women's narratives within an ecological framework of gender based violence reveals not only the conditions under which obstetric violations occur, but also the forms of resilience and coping mechanisms that women develop. This provides a deeper understanding for the long-term health implications of iatrogenic trauma during pregnancy and birth.

Originality/value - This paper discusses obstetric violence from the perspective of women who experience it and contextualises it within the wider life course approach to personhood and maternal transformation.

\title{
1. Introduction
}

The prevalence of bodily violations and coercive behaviour in maternal health practices throughout Latin American countries is well recognised and has been challenged by state institutions, researchers and activists alike (Sadler et al., 2016; Molina et al., 2016; Castro and Erviti 2015; Valdez-Santiago 2013; GIRE 2015). Beyond Latin America, the World Health Organisation (WHO) has declared the mistreatment of women during childbirth and associated human rights violations a 'global problem' (WHO 2014). The 
issue was further highlighted in 2015, as UN and regional human rights experts issued a joint statement explicitly calling on states to address 'acts of obstetric and institutional violence' (ACHPR 2015). Despite this, international and regional standards on abuse and mistreatment of women during birth remain in the early stage of development (Khosla et al 2016).

This paper draws upon first person narratives to examine how obstetric violence is embodied and understood by the women who experience it and what the long-term health implications may be for women who are mothers. The aim of this paper is not to present a 'spectacle of violence' (Das 2007), the violence that women are regularly subject to during birth in Mexican hospitals is already well documented in publications and by women themselves in public forums. ${ }^{1}$ Gathered in the form of life story interviews, the narratives in this article are understood as 'representations of lives, not lives actually lived' (Bruner, 1984). My intention is to foreground the women's own interpretations and memories of events that occurred during pregnancy, birth and early motherhood. In this sense, I do not intend the narratives to be about the nature of the events as such, but about the lives of particular persons who are deeply embedded in them (Das, 2008).

Obstetric violence is a specific form of violence against women that violates their reproductive health rights, and results in physical or psychological harm during pregnancy, birth or puerperium. Perpetrators of obstetric violence are medical professionals of varying status and gender, working within a system that privileges 'obstetric logic' (risk and emergency models of practice) above all else. Manifestations of obstetric violence can include: scolding, taunts, irony, insults, threats, humiliation, manipulation of information and denial of treatment; pain management during childbirth used as punishment, and coercion to obtain 'consent' for invasive procedures, and even acts of deliberate harm to a woman's health (Villanueva-Egan, 2010). High rates of caesarean sections, routine episiotomy, and routine manual examination of the

\footnotetext{
${ }^{1}$ In 2016 the campaign NGO Grupo de Información en Reproducción Elegida held the first Symbolic Tribunal on maternal mortality and obstetric violence with over 300 attendants who heard the testimonies of 27 women who suffered violence during pregnancy or childbirth, and those families who suffered a maternal death. The 27 cases included 10 maternal mortalities, 24 children orphaned as a result of those deaths, 10 stillbirths, and five neonatal deaths, all due to alleged negligence by government health institutions. In all cases where the woman or the family are of indigenous origin, ethnic discrimination was an additional factor (see https://gire.org.mx/en/childbirth-a-violent-experience-forwomen-in-mexico/).
} 
uterine cavity during active labour are indicators of obstetric and institutional violence found to be commonplace in under-funded public institutions in Mexico (Molina et al., 2016; Valdez-Santiago et al., 2013).

Obstetric violence is a product of a multi-factoral framework where institutional and gender based violence (GBV) overlap (GIRE, 2015). It is a form of GBV because it is done to women because of who they are (female reproducers) and what they represent (a risk to high mortality figures). As such, this article situates obstetric violence, and women's experience of it, within an integrated, ecological framework that incorporates the personal, situational, and sociocultural factors that combine to cause abuse and mistreatment. Heise's ecological model provides a basis from which to analyse intersecting factors that influence GBV at different levels of social ecology. Developed from critical analysis of the 'cycle of abuse' approach to intra-familial violence and child sexual abuse, this framework aims to encourage a more integrated approach to theory building regarding gender based abuse (Heise,1998). I use the framework in conjunction with anthropological theories on forms of gender, power and everyday violence (Das, 2008; Abu-Lughod, 1990; Scheper-Hughes, 2004), to examine women's experience and the social aetiology of everyday violence in urban Mexican society. Situating women's narratives within an ecological framework of gender based violence reveals not only the conditions under which obstetric violations occur, but also the forms of resilience and coping mechanisms that women develop. This provides a deeper understanding for the long-term health implications of iatrogenic trauma during pregnancy and birth.

\section{Purpose and significance of the research}

The purpose of this paper is to examine how obstetric violence is embodied and understood by the women who experience it, how it impacts on maternal subjectivity and what the long-term health implications may be. Whilst attention in Mexican research has focused upon quality of services and medical habitus, understanding of the broader social ecology of obstetric violence and its impact on female sexuality and reproductive health remains lacking. Despite twenty-five years of fragmented research and publications on the issue, reports of incidents of abuse in public health institutions continue to rise (Castro, 2014; GIRE, 2015). There is therefore, a growing need for interdisciplinary research in response to the problem and the development of new 
perspectives. The integrated ecological framework, which has already been applied in cross-cultural gender based violence research, provides a basis from which to build upon, and is an interesting heuristic tool for conceptualising future research of obstetric violence.

\section{Methods and sources of data}

This paper is a qualitative, non-clinical analysis of women's experiences of obstetric violence in Mexico. The data discussed in this paper is derived from ethnographic fieldwork carried out in periods between 2010- 2013. The wider ethnographic project explored the transformation to motherhood for low-income mestiza women in a colonial city in Chiapas, South East Mexico.

Three types of empirical evidence support the findings and discussion presented in this paper:

1. Life story interviews with 5 women and 4 maternal health professionals (doctors and midwives) ${ }^{2}$ recorded (audio and handwritten) during periods of fieldwork in 2010, 2011 and 2013. Interviews lasted between 1-3 hours each and were transcribed and translated by the author.

2. A total of 120 hours of participant observation in the waiting rooms of two public hospitals, a prenatal support group in a private birthing centre (in 2010 and 2013 combined), and amongst families at a neighbourhood level (9 months uninterrupted ethnographic fieldwork in 2013).

3. An extensive revision of research on obstetric violence and violations of reproductive rights in Latin American countries (since 2000), reports of cases in popular media (paper and online), recorded complaints and public databases of activist NGOs for women's reproductive rights in Mexico.

The narratives that appear in the section below have been selected in order to represent aspects of childbearing in both the public and private health sector. The

\footnotetext{
${ }^{2}$ I conducted fieldwork with autonomous midwives who are either professionally trained in global midwifery models of care or as local apprentices. They are distinctly different to the indigenous midwife often represented in maternal health research in the Mexican context in both their client base and practices. The autonomous midwives attend mainly mestiza women of low to middle income status and increasingly indigenous women in urban towns and cities. Midwifery is not a recognised profession in Mexico, and as such they are currently denied the status of Skilled Birth Attendant under the World Health Organisation definition.
} 
socio-demographics of the women interviewed in this way ranged from low to middle income status and the women self-identified as either indigenous or mestiza. Using a language of reflection and emotion these women reconstruct events from their imaginations and memories in relation to the transition to motherhood. The intimate, life story approach to interviews provided the women with an opportunity to reflect upon how the birth experience impacted on the initial shaping of their new identity as mothers and how they felt towards their child. For some participants, it was the first time they had described their experience, and the feelings they associated with it, to another person.

\section{Results}

\subsection{Intersecting and conflicting structures of power}

A key theme arising from the narratives is the way in which intersecting and conflicting structures of power are present from the initial interactions with medical professionals through to the moments following birth. When asked to talk about their own transformation to motherhood, women did not narrate events in a linear sequence. Instead they plotted events by jumping from one moment to another, often beginning with the birth and relating back to pregnancy. In narrative, the movement from one time to the next is not linear; it is full of tricks and reversals (Mattingly, 1998), as the person makes sense of their experience. The narratives in the following subsections are interjected with analysis on the themes that arise, however the foregrounding of firstperson narrative is privileged in an effort to remain committed to a woman-centred approach.

\subsection{Pregnancy}

The following excerpts from life story interviews relate to women's experience of prenatal care in public and low-income private institutions in urban Chiapas.

\section{Bety, 24 at time of first pregnancy, married, housewife}

So, when I got pregnant with Adnan I wanted to look for a calm place, where I could trust people. I remembered that there was a hospital run by nuns and they had been part of my childhood ... It wasn't private, they call it a charity hospital, but really the charity isn't much because you pay a high price for going there! I remember investigating and all the other hospitals charged so much money. I didn't want to go to a public hospital because I knew that, if I did they would treat me worse than an old rag ... I couldn't enjoy my first pregnancy because of 
so much stress from the doctor. I was always worried and she was always saying, "let's do an ultrasound because you don't want the baby to have such and such ..." so I was left with this in my head and I started to look everything [that could go wrong] on the internet and learn about all these illnesses which made me even more stressed.

\section{Rosa, 30 at time of pregnancy, single, legal advisor}

All the time I was pregnant I tried to be calm and look after yourself as you should ... Around six months I started to get very itchy all over, very, very itchy ... As time went on, I started to feel worse and so I went to see the doctor that was doing my control prenatal and they did some tests. They checked loads of stuff to see whether it was anything to do with my liver and in the end, they told me that I had intrahepatic cholestasis and that can seriously threaten the baby's life ... they admitted me to hospital for forty days and they did so many tests on me ... In the hospital, they said if I got to seven months, if I still had problems then they would take the baby out so I wasn't putting it at any more risk. They said if I went canary yellow, if my nails went yellow that I should straight away to the hospital. They said that if my wee turned the colour of coco-cola that I should go straight away because it meant that the baby had died. Every day I woke thinking, "my God has the baby moved?" Sometimes it moved and other days it didn't move. I lived in constant fear until I felt the baby move, then I would be okay.

\section{Lupita, 28 first interviewed in final trimester, married, Government office worker} I was going to the [state capital] hospital because of my health insurance. I prefer it here in my home town though because here I can see a midwife or a healer, they are more human. I have a doctor who saw me in the capital, she was very against me going to see a midwife. I didn't like her because she told me I had to take medicine, whether I like it or not. They were iron tablets and they made me feel awful ... I'm very scared, not of the birth, but that there could be complications, I'm doing everything I can to prepare for a normal birth ... [my friends] say that it hurts a lot, but I don't see it as anything I can't handle, we women are made to cope with this type of pain. It's strange because in work they say, "How are you going to have the baby?", "No! Normally?" How Brave!” ... lots of women in the city ask why I'm not having a caesarean they say, "Oh but it doesn't hurt, they just give you an injection and there you go, easy, it's just an operation" ... When I first started control prenatal the doctor always talked about how hard it was to have a baby and when I said I wanted a normal birth she would say "Do you think it's so easy? Giving birth is hard you won't be able to do it normally ..."

Rosa and Bety were preoccupied with a fear of death throughout their pregnancies. Whilst Rosa's fears were rooted in underlying health problems and physical symptoms, Bety's fears were evoked by the risk-based approach to medicine her obstetrician 
employed when answering her questions. In both cases the use of technology appeared to emphasize rather than obviate negative risk - whilst in Rosa's case also giving rise to other potential risks. The pregnancy experience for both women was negatively affected by the fear of death and possible damage caused to their babies. Both of their narratives show the gradual path from happiness to anxiety exacerbated by their interactions with medical professionals and navigating their physical changes and individual responses to pregnancy.

Rosa and Lupita's narratives demonstrate how professionals within the public health system often provide conflicting information that further adds to confusion and stress. The mixed messages also provided a way for the women to negotiate their own bodily experience and knowledge as legitimate. Where women have employment related health insurance, but are not beholden to it, they can avoid potential maltreatment or coerced intervention (such as elective caesarean section). It is during the pregnancy period when women appeared to express most agency in their choices of maternal health management.

\subsection{Birth}

Below the women describe what was happening from their memories of what was happening around them. The narratives of Rosa and Bety are complimented with other women to provide a comparison of experience across socio-economic and ethnic boundaries. The births described below culminated in outcomes of either emergency caesarean or vaginal birth. The births took place in a mixture of public and private hospitals.

\section{Bety (Charity Hospital.)}

When I got to the hospital we arrived in the night time and honestly, I thought the doctor was going to stay with me ... but it wasn't like that ... It's very annoying that [the nurses] just came in and did internal examinations and then left and then returned and did another ... and you can't just be in comfortable clothes or you want to get up. It's your instinct to want to stand up but you can't because they've put a drip in you ... You don't really know how much [Pitocin] they're putting in because the doctor would enter and say "Right, give her another injection," and the they would leave and after about forty minutes they'd come back again ... and then [the doctor] said "Oh this is taking a long time, I think we're going to consider a caesarean." I felt very bad because I really didn't want a caesarean and my husband, I think for his lack of knowledge on this subject he was saying to me, "Well if the doctor is saying this is what you need 
there must be a reason" ... it's like this thing that you've dreamed about being beautiful and lovely very quickly turns into suffering ... The doctor without even asking my opinion just said, "We have to break the waters now," and put this thing inside me. It was long and metal and shaped like a needle. And so water came out and it was green ... She said, "Now it's an emergency caesarean. We can't wait any more time because the baby will start to eat poo and if it does it ..." and so you can imagine how that must feel, a woman in the middle of labour and the doctor tells you that your baby could die, so you say, "Okay, do what you want."

\section{Felisa 19 (at time of pregnancy), single, student (public hospital)}

When I got my first pains I thought the baby would be born, I didn't know, it was my first time... I went to the [public assistance] clinic and they told me I had a lot longer to go, that I wasn't open yet and I should walk around. My waters broke and I couldn't stand the pain. I knew they wouldn't take me at the clinic so I went to the Central Maternity Hospital. I was with my brother. They said that my waters had broken so the baby had to be born. They said the baby's neck was in the wrong position so it couldn't be born normally. They said I needed a caesarean. I told them I didn't want one and they said if I didn't have one my baby would die, that I might die. I said I didn't want one ... I wouldn't sign the paper, so they told my brother and he signed it instead and they took me and did the caesarean. They cut me in a straight line from my bellybutton to down below. ${ }^{3}$ They said it would heal better that way ... it didn't hurt when the baby was born, but after oooh it was painful. The nurses were nice to me, they knew I was alone so they helped me with the baby ... They didn't charge me a lot because they knew I was on my own ... It wasn't the cost of the caesarean that was hard, it was the medications I needed afterwards. They cost about six hundred pesos, which I had to borrow from my boss.

Elbi 30 at time of pregnancy, married, solicitor (private middle-income hospital) After we arrived [at the hospital] they did an ultrasound and said that the cord was around the baby's neck and that they would have to do an emergency caesarean. I was very nervous as I didn't know any of the doctors or nurses there. I was really upset because I had dreamt of a natural birth. I said I couldn't decide and would have to call my husband ... It was then they started to put pressure on me and say I would have to decide because the baby's life was in danger. All throughout these conversations they were prepping me for surgery. They said that if I didn't agree and the baby died then it would be my fault and not theirs ...

\footnotetext{
${ }^{3}$ Here Felisa is referring to the classical or vertical incision which was common practice in this particular hospital. Medical justification for the vertical incision is for speed of access to the uterus. Although this is undoubtedly an advantage in emergency situations, the disadvantage to the woman is in the scarring left behind, damaged muscle tissue, longer healing time in addition to the risks of caesarean section overall (Gonzalez-Perez et al., 2013; Gibbons et al., 2010).
} 
By this time the contractions were really strong and I couldn't think straight ... In the end, I agreed as long as they didn't knock me out completely ... I remember the staff chatting over me about their lives; I felt invisible. They did the caesarean and the baby was fine ... when I think about it I feel like a failure.

\section{Rosa (public hospital for government employees)}

We had arrived at 4am and at 8am they gave me a bed and the hours passed none, ten, eleven. They said they wouldn't let it go past $2 \mathrm{pm}$. I was in so much pain. I said at one point to the doctor, "I don't understand, why won't my baby come out?" He said, "It's because you're not trying hard enough." So I started to push a lot and still it didn't come out, and I started to think it was strange that it wouldn't be born. Other women came and went so why not me?... I was trying so hard but it wouldn't budge ... in the end they said to me, "Señora your baby is stuck. If anything else goes wrong then we will have to do a caesarean. If you don't try harder the baby won't be born." So I thought, "Okay, I'll carry on," and finally, I thought it was going to be born. A doctor came by and said, "Well are you ready to have this baby?" He put his hand inside me and said the baby was stuck behind a membrane. After that the labour pains were a lot worse because he broke the membrane and because he kept putting his hand inside me during contractions, or putting things in me, I had no idea what he was doing. And then he said, "Right, I think one more big push and your baby will be born ... And then with one last try they took to the delivery room and he was born, and I was the happiest woman alive! ... [the doctor] said straight after the birth, after the placenta came out, "We're going to put an IUD in," and I said no, that I didn't want one. He said that I would die if I got pregnant again and that I should learn from what happened to me. In these moments, I don't think you are capable of making a decision ... He just said, "Señora you will die if you have another child." ... He said they would put the IUD in and I said no, so then he got angry and said, "You are irresponsible, wanting to bring another child into this world, put another child in danger. You are a bad mother because you want to bring another baby into the world to suffer."

The women's birth narratives raise questions about what creates the conditions for an emergency, from whose perspective and how language and relationships of power shape the unfolding of events. The construction of what constitutes a medical emergency, in a labouring and birth situation, makes for an interesting point of analysis. Within this analysis power reveals itself as part of the everyday conditions of emergency in the hospital environment. Framed within the medical lexicon of emergency (evoking the drama of life or death) acts of violence become rationalised by both perpetrators and victims as a means to an end. 


\subsection{Nurturing}

In the excerpts below Bety and Rosa describe how the birth shaped their experiences of the postpartum and early nurturing period.

Bety

From the moment I got home I found it really difficult. It wasn't what I had imagined but I thought maybe after a few days I'll be able to start doing things around the house, but I couldn't. I felt like my body had let me down. I was angry with myself and irritable with the baby ... I would go into the kitchen and have suicidal thoughts, you have no idea how it is to walk around your house and everything you see you think about how you could use it to kill yourself ... After the caesarean, [my body] took a long time to heal. But they say that the depression has something to do with it, that your body doesn't heal well after the surgery because you feel down. My husband always helped me with curing the wound; he helped me wash and clean it. He said a few times that he noticed puss coming from the wound. That's why I had antibiotics afterwards. But speaking of the wound, the most interesting thing for me is that the wound doesn't stay in your body, the wound is in your heart. Because it's an experience that, although consciously you are saying that you've got over it, when suddenly you get thoughts or reminders that really you haven't got over what happened. It's then you realise that everything that happened is still there ... When you learn you can let go, that nothing will happen, it will go and you will feel better, that's really when the scars begin to heal and begin to disappear ...

Rosa

I wouldn't like to repeat the experience; I wouldn't like so many people to see my body again. It was lovely to have a child, but the process of having all these people touch you. That was horrible and it wasn't even just one doctor it must have been about seven different people putting their hands inside me ... they were all male doctors apart from one and also they were all really mean. I heard them say to other women who were screaming out [in pain], they would say "Oh yes, and I bet you didn't scream like that when you made the baby". That's why I didn't cry or anything. I supressed all my feelings because I didn't want them to shout the same things at me. They were saying to all the women that cried "Why are you crying? This is no reason to cry. When you did it you weren't crying were you?" I waited till I got home, when I was alone in my house I thought about the whole situation and I cried ... being a mother is a beautiful thing and it was worth it, though only once! Two or three times more maybe but I am too scared because of what happened ... I don't like having this thing [IUD] inside my body; it has brought about drastic hormonal changes that I don't like. But to be honest I don't want to go through that again so for now I will keep it ... My partner said to me, "Why don't you take it out?" But I think he's doing it just because he wants to keep me always for him. He thinks he'll 
secure me with one more child. You see in Mexico a man won't accept a woman with two children, not even one. ${ }^{4}$

Withdrawal from medical professionals during the postpartum period (either through choice or lack of provision) resulted in many women dealing with unanswered questions regarding the interventions at birth - which they then began to turn in on themselves. Many of the women I listened to during fieldwork spoke of coming to terms with a feeling of failure, humiliation and loss of expectations. Women are often left with conflicting emotions and analyse their behaviour during pregnancy and birth, searching for answers of how and where it went wrong. A common theme in the narratives presented in this paper is that, although women felt shamed and humiliated by professionals, more than this, they felt let down by their own bodies. The women who underwent emergency caesarean sections spoke of a sense of failure, which took time to reconcile, and impacted upon them as maternal subjects.

\section{Discussion}

The ways in which women interpret violence in healthcare settings, in relation to the wider context of their lives and feelings about who they are, has significant implications for evaluating the effectiveness of universal approaches to reproductive and maternal health. In this research two interconnecting themes have arisen for discussion:

\subsection{Women's perspectives on obstetric violence}

In presenting these narratives the intention is not to question the clinical decisionmaking of the health professionals involved. This discussion is not intended to deny that complications can happen during pregnancy and childbirth. The maternal and infant mortality rates in Chiapas are amongst the highest in Mexico, and this will undoubtedly shape how frontline medical workers perceive childbearing and childbirth. Despite this, the argument arising from the narratives is not about the reality of emergencies per se, but about the conditions within which they emerge and become politicised in an institutional setting.

\footnotetext{
${ }^{4}$ Rosa was in a long-term relationship with a man who was separated from his wife, but whom he refused to get divorced on the grounds that his children from that marriage would suffer. Their relationship had been kept secret for eleven years and they continued in this way after the birth of her son. At the time of the interview Rosa was considering ending the relationship.
} 
Aside from analysis of medical decision making (as occurs in previous studies), it is important to think about what can be learnt from how women interpret and experience acts of obstetric violence. Although they may not use the same terminology as activists and policy makers, my interlocutors describe violations of bodies and lack of agency from an embodied perspective. Yet, the narratives also reveal ways in which women employ tactics (silence, avoidance, opportune decision-making) that they often use in other aspects of their lives to deal with everyday forms of oppression and violence.

The incorporation of women's narratives into a broader ecological model of obstetric violence reveals a more complex social aetiology. Paying greater attention to more subtle forms of power and resistance throughout the socially situated process of pregnancy, birth and early motherhood highlights ways 'in which intersecting and often conflicting structures of power work together' (Abu-Lughod, 1990). Further, it demonstrates how forms of bio-power permeate beyond institutions and are inseparable from the wider culture of GBV.

\subsection{Situating obstetric violence in an integrated ecological framework}

Current evidence and theorizing on how and why obstetric violence occurs in Mexican institutions (and elsewhere) tends to focus predominantly on standards of medical practice and behaviours of professionals within an institutional context. Whilst it is important to deal with these factors, this does not consider the broader inter-play of personal, situational and socio-cultural factors. The institutional habitus perspective (see Castro, 2014; Smith-Oka, 2013) is helpful in challenging the universal assumption that reproductive health workers are best placed to identify and treat the effects and triggers of GBV. However, a purely institutional focus results in recommendations that only target improvements to medical education and practice. If recommendations continue to focus on making medical practice more humanized in a non-humanized violent society the context remains problematic.

Many of the women I encountered in the field spoke of coming to terms with a feeling of failure, humiliation and loss of expectations. Women described being left with conflicting emotions and began to analyse their behaviour during pregnancy and birth, searching for answers of how and where it went wrong. A common theme in the narratives presented in this paper is that, although women felt shamed and humiliated 
by professionals, more than this, they felt let down by their own bodies. The women who underwent emergency caesarean sections spoke of a sense of failure, which took time to reconcile, and impacted upon their maternal and female subjectivity.

An integrated ecological framework recognises that GBV in the form of violence against women, results from the interaction of factors at different levels of the social environment (Heise et al., 2002). Analysing the phenomenon of obstetric violence beyond the institution and recognising the long-term impact on women's health and maternal well-being will result in better, more effective strategies for change.

\section{Conclusion}

In foregrounding women's narratives of obstetric violence, this paper has contextualised their experiences within a wider life course approach to personhood and maternal transformation. Childbearing and childbirth happen in a medical, social and economic context that has the capacity to shape a woman's maternal subjectivity and personhood beyond the events of birth. Situating women's narratives within an ecological framework of gender based violence reveals not only the conditions under which obstetric violations occur, but also the forms of resilience and coping mechanisms that women develop. This in turn provides a deeper understanding and promotes consideration of the long-term health implications of iatrogenic trauma during pregnancy and birth.

\section{References}

Abu-Lughod, L. (1990), The Romance of Resistance: Tracing Transformations of Power Through Bedouin Women. American Ethnologist, Vol. 17 No. 1, pp. 41-55.

doi:10.2307/645251

African Commission on Human and People's Rights (ACHPR) (2015), Joint Statement by UN human rights experts, the Rapporteur on the rights of women of the Inter-American Commission on human rights and the Special Rapporteurs on the rights of women and human rights defenders of the African Commission on human and peoples' rights, available at http://www.achpr.org/news/2015/09/d192/ (accessed $4^{\text {th }}$ January 2016) 
Bruner, E. (1984), "The Opening Up of Anthropology in E. Bruner" (Ed.), Text, Play, and Story: The Construction and Reconstruction of Self and Society Washington D.C., The American Ethnology Society pp. 1-6

Castro, R. (2014), Génesis y práctica del habitus médico autoritario en México. Revista Mexicana de Sociología, No. 76, pp. 167-197.

Castro, R. and Erviti, J. (2015), 25 años de investigación sobre violencia obstétrica en México, Revista Conamed, Vol.19 No.1, pp. 37-42.

Das, V. (2007), Life and words: violence and the descent into the ordinary, Oxford, Oxford University Press.

Das, V. (2008), Violence, Gender, and Subjectivity, Annual Review of Anthropology, Vol. 37, pp. 283-299.

Gibbons, L., Belizán, J. M., Lauer, J. A., Betrán, A. P., Merialdi, M. \& Althabe, F. (2010), The Global numbers and costs of additionally needed and unnecessary caesarean sections performed per year: overuse as a barrier to universal coverage, World Health Report, available at: http://www.who.int/healthsystems/topics/financing/heal threport/30Csectioncosts.pdf (accessed September 2013)

GIRE (2015), Violencia obstétrica. Un enfoque de derechos humanos: GIRE, available at: http://clacaidigital.info:8080/xmlui/handle/123456789/677 (accessed 12th September 2015)

Gonzalez, G. F., Tapia, V. L., Fort, A. L. \& Betran, A. P. (2013), Pregnancy outcomes associated with Cesarean deliveries in Peruvian public health facilities. International Journal of Womens' Health, No.5, pp.637-45. doi: 10.2147/ijwh.s46392

Heise, L. Ellsberg, M., \& Gottmoeller, M. (2002), A global overview of gender-based violence, International Journal of Gynecology \& Obstetrics, Vol. 78 Suppl. 1 S5-S14.

Heise, L. L. (1998), Violence against women an integrated, ecological framework. Violence Against Women, Vol.4 No. 3, pp. 262-290.

Khosla, R., Zampas, C., Vogul, J. P., Bohren, M. A., Roseman, M., \& Erdman, J. N. (2016), International Human Rights and the Mistreatment of Women During Childbirth. Health \& Human Rights: An International Journal, Vol. 18 No. 2, pp. 1-15

Mattingly, C. (1998), Healing dramas and clinical plots: the narrative structure of experience. Cambridge, Cambridge University Press.

Molina, R. L., Patel, S. J., Scott, J., Schantz-Dunn, J., \& Nour, N. M. (2016), Striving for Respectful Maternity Care Everywhere. Maternal and Child Health Journal, pp.1-5. doi:10.1007/s10995-016-2004-2

Sadler, M., Santos, M. J. D. S., Ruiz-Berdún, D., Rojas, G. L., Skoko, E., Gillen, P., and Clausen, J. A. (2016), Moving beyond disrespect and abuse: addressing the structural 
dimensions of obstetric violence, Reproductive Health Matters, Vol. 24 No. 47, pp. 47-55. doi: http://dx.doi.org/10.1016/j.rhm.2016.04.002

Scheper-Hughes, N. (2004), Dangerous and Endangered Youth: Social Structures and Determinants of Violence. Annals of the New York Academy of Sciences, Vol. 1036 No. 1, pp. 13-46. doi:10.1196/annals.1330.002

Smith-Oka, V. (2013), Shaping the Motherhood of Indigenous Mexico. Nashville, Vanderbilt University Press.

Valdez-Santiago, R., Hidalgo, E., \& Mojarro, M. (2013), Nueva evidencia a un viejo problema: el abuso de las mujeres en las salas de parto. Rev CONAMED, Vol. 18 No.1, pp.14-20.

Villanueva-Egan, L. A. (2010), El maltrato en las salas de parto: reflexiones de un ginecoobstetra, Revista Conamed, Vol.15 No3 pp.147-151

World Health Organization (WHO). (2014), The prevention and elimination of disrespect and abuse during facility-based childbirth: WHO statement, available at: http://apps.who.int/iris/bitstream/10665/134588/1/WHO RHR 14.23 eng.pdf?ua=1 $\underline{\& u a=1}$ (accessed 10 ${ }^{\text {th }}$ March 2015) 